\title{
Životní prostředí je darem a závazkem
}

\section{Jiří Nečas}

Envigogika 8 (3) - Inspirace (Nerecenzované články)/ Inpiration (Non-reviewed articles)

Publikováno/published 15. 10. 2013

http://dx.doi.org/10.14712/18023061.393

\section{Abstrakt}

Článek je obhajobou křest́anského pohledu na ekologickou problematiku - k němu patří vědomí odpovědnosti za přírodu jakožto Boží stvoření. Autor analyzuje antropocentrický postoj a rozebírá důvody, proč je někdy těžké se $v$ otázkách životního prostředí angažovat i pro samotné křestáany.

\section{Abstract}

The article is a defence of the Christian perspective concerning environmental issues to which belongs a sense of responsibility for nature as God's creation. The author analyzes anthropocentric position and discusses the reasons why it is sometimes difficult to engage in environmental issues even for Christians themselves. 
Křest́anství bývá někdy kritizováno, že se podílí na současné necitlivosti vưči životnímu prostředí. Ta sice své kořeny $v$ takzvaně křestanském prostředí euroamerické civilizace má, avšak je především produktem ateistického osvícenství. Llyn White ve své známé kritice křestáanství jako zdroje myšlení směřujícího ke ztrátě vztahu k prostředí, publikované r. 1967, vychází z toho, že mnohá stará místní pohanská předkřestáanská náboženství často situovala svá božstva do prvků prírody - do stromů, do skal apod. -, čímž byl podporován určitý vztah úcty a bázně. Člověk bohatost přírody nepřijímal jako samozřejmost, s níž lze libovolně nakládat. Je pravda, že z křest́anského hlediska přírodní objekty nejsou božstvem ani sídlem božstev, avšak celá príroda je Božím dílem, krásným a dobrým, svěřeným člověku $k$ užívání a $k$ opatrování. Tuto skutečnost si bytostně uvědomoval a prožival sv. František z Assisi, u většiny křestáanských myslitelů minulosti však nebyla zdůrazňována. Přitom křestáanství, založené na učení Ježíše Krista a na Bibli, je daleko lepším základem pro vytváření vztahu mezi člověkem a prostředím, než by mohl být jakýkoli pohanský kult. K současnému křestáanství vědomí odpovědnosti za životní prostředí patří. Česká křestanská akademie má svou Ekologickou sekci, Českobratrská církev evangelická má svůj Poradní odbor pro otázky životního prostředí, v ČR pưsobí Česká křestáanská environmentální sít a organizace $\underline{A}$ Rocha - křestané v ochraně prírody obě poslední zmíněné organizace spolupracuji s př́slušnými organizacemi nadnárodními.

Určité více méně okrajové odmítání zájmu a angažovanosti pro životní prostředí však mezi křestáany přežívá. Někdy bývá odůvodňováno tím, že je to ztráta času, že se nedá stejně už nic dělat $(A)$, někdy je nedomyšleným důsledkem odmítání čehokoli pozemského $a$ orientací jen $k$ tomu, co se týká věčnosti (B). $K$ oběma těmto námitkám, jež jsou $v$ rozporu se skutečným křestáanstvím, založeným na Ježíši Kristu a na Bibli, se ještě vrátíme (odvoláme se na ně jako na námitku A resp. B).

Na začátku Bible čteme o stvoření světa, o stvoření kosmu. Jde o hluboké alegorické líčení ukazující jednotu celého díla stvoření, zdůrazněnou sedmým dnem, dnem Božího ${ }^{1}$ odpočinutí. Environmentalisty je často zmiňovaná námitka, že Bible je př́liš antropocentrická, je důsledkem určitého nepochopení skutečnosti, že Bible se obrací k člověku, člověk je adresátem jejího sdělení. Člověk ale podle Bible může a má stvoření ${ }^{2}$ přijímat jako dar ${ }^{3}$ a v dobrém je užívat, má je vzdělávat a pečovat o ně ${ }^{4}$, je tedy pro něho i závazkem. A nejde jen o vztah člověka a ostatního stvoření, nýbrž také o vztahy mezi lidmi navzájem. Aby člověk svou úlohu mohl plnit, obdařil ho Stvořitel rozumem, schopností poznávat. Člověk má svět poznávat, aby své poslání plnil, aby byl s to o stvoření pečovat a vzdělávat je, aby si mohl opatřovat, co $\mathrm{k}$ životu potřebuje, a přitom aby neškodil druhým lidem ani př́rodě. Křestanský pohled na svět a př́stup potřebuje jak čistá i aplikovaná věda, tak i technika a ekonomie.

1 Př́́davné jméno Boží se používá ve významu přídavného jména přivlastňovacího k podstatnému jménu Bůh.

2 Bylo by možné mluvit o bytí, světě či vesmíru; slovo stvoření má zdůraznit, že z křestanského pohledu jde o Boží dílo.

3 Gn.1.26-29. Základní informace o Bibli a citacích z ní je na konci článku.

4 Gn.2.15. Závazek vůči zemi se vším, co je na ní, je zde vyjádřen slovesy "obdělávat a střežit". Idea úkolů uvnitř stvoření (civilně: v rámci životního prostředí) je i ve výše citovaném oddíle Gn.1.26-29; použité sloveso panovat neznamená „vyčerpávat" či "ničit", ale „v dobrém užívat" a "pečovat”. 
Druhá až pátá kniha Mojžíšova obsahují pravidla pro lidské jednání. Za jejich stěžejní část je pokládáno Desatero Božích přikázání ${ }^{5}$. To není direktivním kodexem, nýbrž především ukazatelem, jak žít. Výzva $\mathrm{k}$ úctě $\mathrm{k}$ jedinému Bohu, která vede $\mathrm{k}$ odbožštění př́rody, Whitem kritizovanému, chce zbavit člověka závislosti i na takových životnímu prostředí nebezpečných "pohanských božstvech", jakými jsou HDP (Daly 1973), přepychové automobily, nákladné zahraniční cesty apod. Výzva světit sedmý den má člověku umožnit zastavit se od všeho shonu a spěchu, mít čas na rozjímání, pro zdravý život tolik potřebné, mít čas na rodinu, na prátele, uvědomit si, že pravé hodnoty leží jinde než $v$ penězích a věcech za ně směnitelných. Motivuje tak $k$ životnímu prostředí př́znivému způsobu života. Přikázání "nezabiješ" vede k úctě k životu jako takovému, přikázání "nepokradeš" a "nepožádáš" ukazují, že člověk nesmí žít na úkor druhých, že je třeba umět se s druhými sdílet o Boží dary, umožňující a obohacující život.

Křest́anská Bible se skládá ze dvou částí. Starší a rozsahem větší je Starý Zákon, svaté Písmo Židů; pro křest́any stěžejní je však Nový Zákon, obsahující svědectví o Ježíši Kristu a prvotní křestáanské církvi. Vztah obou těchto částí Bible výstižně vyjadřuje dvojpřikázání lásky: ,Miluj Hospodina, Boha svého, z celého svého srdce, celou svou duší, celou svou silou a celou svou mysli' a 'miluj svého bližního jako sám sebe'6. $\mathrm{V}$ těchto dvou „přikázáních", která jsou citátem ze Starého Zákona7, vidí Ježís shrnutí všech ostatních přikázání včetně Desatera. Láska k Bohu má beze sporu i svou pozemskou dimenzi, která $v$ citátu $z$ Lukášova evangelia je vyjádřena zařazením mysli i síly. Milovat Boha znamená $i$ přemýšlet, jak dobře s tím, co On stvořil a na čem Mu záleží zacházet a přiměřeně jednat, jak se angažovat ve prospěch dobra. Láska k bližnímu se týká především tohoto světa a života $v$ něm. Milovat bližního, tedy druhého člověka, znamená se s ním spravedlivě sdílet. A není důvod, proč při tom nemyslit i na lidi v budoucích generacích.

Víra je pro křestana motivací pro určitý způsob jednání, pro přijetí určitých rozhodovacích kritérí. Do nich se promítá (či aspoň má promítat) výzva k lásce $k$ Bohu a bližnímu. Stupnice hodnot běžná $v$ naší sekularizované společnosti pohledem biblického (Ježíšova) učení neobstojí. Ona však neobstojí ani z hlediska požadavku udržitelnosti. Josef Vavroušek při různých přiležitostech stavěl proti sobě hodnoty běžně přijímané $v$ naší civilizaci s hodnotami, které jednak odpovídají člověku v celé šíři a hloubce jeho osobnosti, jednak jsou v souladu s požadavkem udržitelnosti (Keller 1995, Keller 1996, Vavroušek 1994, Vavroušek 1995). Tyto hodnoty patří k Ježíšově etice, kromě dvojpřikázání lásky hutně vyjádřené $v$ Jeho Kázání na hoře ${ }^{8}$ a vinoucí se celým Jeho učením a jednáním. Přirozeně, že mezi Vavrouškovým a Ježíšovým hodnotovým systémem nelze dělat rovnítko; Ježíš bere $v$ úvahu i tu komponentu bytí, která přesahuje materiální svět, avšak pozemský život nepodceňuje a neopomíjí.

Bible svědčí o neustálém Božím zájmu o stvořený svět, lidským hříchem ${ }^{9}$ porušený: Nebot' Büh tak miloval svět, že dal svého jediného Syna, aby kdo v něho věří, nezahynul, ale měl život věčný (J.3.16). Láska $\mathrm{k}$ Bohu tak nutně vede $\mathrm{k}$ pozitivnímu tvưrčímu zájmu o

5 Ex.20.1-17; Dt.5.6-21. V textu desatera je 12 slovesných imperativů; v dělení do 10 přikázání jsou mezi jednotlivými církevními tradicemi drobné rozdíly, a proto se na jejich pořadová čísla neodvolávám.

6 Lk.10.27

7 Lv.19.18; Dt.6.5

8 Mt.5-7

9 Prosím čtenáře, jimž slovo hřích je "cizí", aby je přijali intuitivně. Jeho podrobnějším objasňováním bychom se dostali mimo rozumný rozsah článku. 
svět, k co nejlepšímu zacházení se světem, Bohem stále milovaným, a tedy i k osobnímu nasazení ve prospěch životního prostředí. Odmítání čehokoli pozemského je tak v rozporu se samým základem křestanství (odpověd’ na námitku B), které nabádá k následování Krista, k přijetí Krista za vzor. V Jeho životě mezi lidmi se plně uplatňoval jak vertikální rozměr - pohled k věčnosti, tak i rozměr horizontální - plně prožívaný život v časnosti; nejenže uzdravoval a jinak pomáhal, nýbrž uměl s druhými sdílet i chvíle při společném jídle či poháru vína. Jeho etika má důležitý pozemský rozměr. Ukazuje, že je možné žít plně a bohatě, a přitom zůstat zdravě skromnými, při vědomí, že to, co k životu potřebujeme - dary prírody - vzácné Boží dary - tu jsou nejen pro nás, nýbrž i pro druhé; toto vědomí vzájemnosti přináší všestranné obohacení životů.

Poctivě vytvořené prognostické studie o naší planetě jako celku radostné nebývají. IPCC (Mezivládní panel pro změny klimatu) v záŕí 2013 uvedl, že s 95\% pravděpodobností je dominantní př́činou současné změny klimatu lidská činnost. A psychologové a sociologové dodávají, že člověk se nezmění. Ekonomové a politici vzbuzují domněnky, že takovou změnu ani nechtějí. To vede $\mathrm{k}$ určitému pesimismu, jímž se i někteří křestané nechávají ovlivnit. Takový př́stup ovšem odporuje víre $v$ Boží moc a v Jeho zájem o svět. Tato víra vede ke konání dobra, tedy i k zájmu a osobnímu nasazení pro životní prostředí. Dobré jednání se stává vyjádřením modlitby, $v$ našem př́padě modlitby za svět, za př́rodu, za životní prostředí. Křestáan věrí, že Bůh může stav světa ovlivnit, dokáže se přiznat $k$ dobrým snahám (odpověd' na námitku A). Třeba tak, že dojde k něčemu, co sice neodporuje našemu poznání světa a prírody, ale jeví se jako velmi nepravděpodobné. Podle zmíněných představ odborníků v sociálních vědách se člověk nezmění. Ale opravdu není změna lidských srdcí možná? Podle našeho poznání je nepravděpodobná, ale není nemožná. A pro budoucnost planety Země je nutná! Je na všech lidech dobré vưle, kteréhokoli náboženského vyznání i bez vyznání, aby hledali cestu k vzájemnému dorozumění a porozumění a společně usilovali o dobro pro celý svět, pro prírodu, pro životní prostředí, pro dobré Boží stvořitelské dílo. 


\section{Dodatek.}

Základní informace o Bibli. Křestáanská Bible se skládá ze Starého a Nového zákona; obě tyto části jsou tvořeny jednotlivými knihami (zpravidla se označují zkratkami), které se dělí na kapitoly a ty dále na verše. Biblické citace tedy označují zkratku knihy, číslo kapitoly a číslo verše. Jednotlivé části citace jsou v tomto článku oddělovány tečkami, značka "-" (až) je používána v obvyklém smyslu.

V židovské tradici se Písmo (tedy Starý zákon) dělí na "Zákon", „Proroky" a "Spisy". Zákon je tvořen 5 knihami Mojžíšovými (Genesis Gn, Exodus Ex, Leviticus Lv, Numeri Nu a Deuteronomium Dt). Prvních 11 kapitol knihy Genesis má charakter legendy, která líčí počátek bytí a na něm ukazuje postavení člověka $v$ něm, vztah mezi člověkem a Bohem, vztah mezi člověkem a ostatním světem atd. Stručně Ize říci, že od Gn.11.10 je obsahem Zákona prehistorie Izraele jako Božího lidu.

Na další starozákonní knihy se zde neodkazujeme.

V Novém zákoně 4 evangelia (Matouš Mt, Marek Mk, Lukáš Lk a Jan J) líčí pozemský život Ježíše Krista; Skutky apoštolů jsou jakousi kronikou první církve. Značnou část novozákonních knih tvoří apoštolské dopisy (epištoly) a poslední knihou je zde Apokalypsa (Janovo zjevení). V textu článku jsou jen odkazy na evangelia. Avšak i další novozákonní knihy obsahují místa vedoucí $\mathrm{k}$ vytváření hlubokého pozitivního vztahu $\mathrm{k}$ přírodě, např. Ř.8.19-23, Kol.1.15-20 (Pavlova epištola do Říma, resp. do Kolos).

\section{Literatura}

- Daly, H: Toward a Steady-State Economy. San Francisco, Freeman 1973.

- García Rubio, A.: Dominad la Tierra? Barcelona, Centro de Estudios „Cristianisme i Justícia" (Fundación Lluís Espinal) (http://www.fespinal.com/espinal/llib/es54.pdf).

- Gordonová, A. - Suzuki, D: Jde o přežití. Beroun, Baroko \& Fox 1993.

- Gore, Al: Země na misce vah. Praha, Argo 1994. (Orig.: Earth in The Balance. Boston, Houghton Mifflin 1992.

- Heller, J.: Životní prostředí v pohledu biblického poselství. In: Heller, J.: Pozdní sklizeň. Praha, Advent-Orion 2000

- IPCC 1913: Working Group I Contribution to the IPCC 5th Assessment Report. Climate Change 2013: The Physical Science Basis. Final Draft Underlying ScientificTechnical Assessment.

- Keller, J.: Přemýšlení s Josefem Vavrouškem. Praha, G+G 1995.

- Keller, J. - Gál, F. - Frič, P.: Hodnoty pro budoucnost. Praha, G+G 1996.

- Kohák, E.: Zelená svatozáŕ. Praha, SLON 1998.

- Moltmann, J.: Bůh ve stvoření. Brno, CDK 1999.

- Nováček,P.: Chválí Tě sestra Země. Olomouc, Matice cyrilometodějská 1998.

- Teologické texty 5 (1994), č. 1. 
- $\quad$ Teologické texty 8 (1997), č. 5.

- Universum č. 16.

- Vavroušek, J.: Hledání možnosti trvale udržitelného rozvoje. Křest́anská revue, 62 (1995), č.2.

- Vavroušek, J.: Hodnoty a trvale udržitelný způsob života. Teologické texty 5 (1994), č. 1.

- White, L.: The Historical Roots od Our Ecological Crisis. Science, 155,1967

RNDr. Jiři Nečas

Matematik a laický kazatel v Českobratrské církvi evangelické

Zabývá se mj. vztahem přírodních věd (fyziky, ekologie), etiky, ekonomie, teologie a dále dopravní politikou a prognostikou.

e-mail: JorgeMalTiempo@seznam.cz; web: http://jiri_necas.jetmouse.cz/ 